\title{
INDUCTION OF SYSTEMIC DISEASE RESISTANCE IN CUCUMBER PLANTS TREATED BY THE SPRAY OF SOME BIOTIC AND ABIOTIC AGENTS TO CONTROL DOWNY MILDEW DISEASE
}

\author{
KHALIL, M.E. and E.M.A. ASHMAWY \\ Integrated Pest Management Dept, Plant Pathology Institute, Agricultural Research \\ Center, Egypt
}

(Manuscript received 13 March 2019)

\begin{abstract}
$\mathrm{C}$ ertain amounts of inducers, i.e Salicylic acid, Oxalic acid, and yeast extract as biocontrol agent as well as the fungicide Aquacid, used as foliar spray treatments proved to be effective in reducing downy mildew severity (DS) caused by (Pseudoperonospora cubensis) on cucumber plants under greenhouse and field condition. In vitro, the tested fungicide, resistance inducing chemicals (RIC) and biocontrol agent highly inhibited sporangial germination of $P$. cubensis fungus compared with the control, Aquacid fungicide and the biocontrol agent were more effective on sporangial germination than chemicals RIC. Under greenhouse condition, severity of downy mildew disease decreased, significantly. Some Plant growth parameters i.e Plant length and fresh weight were significantly increased when the fungicide and RIC were applied as compared with the control. In field experiments, foliar application with fungicide Aquacid $(2.5 \mathrm{~g} / \mathrm{L})$ as a comparison treatment, Salicylic acid, Oxalic acid, and the yeast extract in concern, significantly reduced the disease severity of downy mildew with the averages of 7.25, 25.43, 30.0 and $16.40 \%$, respectively compared with untreated plants in the first season 2016 and the same trend was cleared in the second season 2017 with the averages of $6.50,24.15,25.45$ and $13.33 \%$, respectively. Moreover, all exercised treatments significantly increased all of the studied growth parameters, i.e. plant length, leaves number, number of flowers, fresh and dry weight/plant. The treatments showed remarkable increase physiological aspects (Peroxidase activity and total phenol content) and similar reduction in disease severity of downy mildew revealing the most superior positively correlation with both peroxidase activity and total phenol content.

Key words: cucumber, downy mildew, induced resistance, dry yeast, fungicide, peroxides activity, total phenol content.
\end{abstract}

\section{INTRODUCTION}

Cucumber (Cucumis sativa L.) is one of the most important and popular vegetable crops all over the world and Egypt as well. The crop is mainly cultivated during the summer season in open field, while it could be grown in two growing seasons, i.e., autumn and spring under plastic house conditions.

Downy mildew of cucurbits caused by Pseudoperonospora cubensis [(Berck and Curts) Rostow] is a serious disease problem worldwide and causes considerable economic losses to the cucumber crop especially under greenhouse conditions 
(Muhammad et al. 2014 and Sujoy et al. 2017). It was surveyed for the first time in Egypt on cucumber grown in the open field by El-Helaly et al. (1963). The causal pathogen attacks many members of the family Cucurbitaceae. In case of severe infection, the disease results in destructive losses in both open fields and protected cultivation (Spencer, 1981 and Varary and Ducrat, 1989). In Egypt, El-Nagar et.al. (1991) expected $30-80 \%$ yield losses if severity of infection reached $50-100 \%$. The disease is considered the most serious problem in the greenhouse, where warm wet weather promotes disease development; severely infected leaves may die in 10 to 14 days (Shama et al., 1998). however,Although, chemical synthetic fungicides succeeded to control several plant diseases, they increase production cost, incidence of health problem and pollution of environment. Therefore, a need of alternative strategies has arisen for controlling plant diseases. (Gullino et al., 1999 and Chiu, and Huang, 2014).

Salicylic acid and Oxalic acid were reported for inducing resistance in many plants and reducing fungal diseases (El-Gamal et al., 2007, Abada et al., 2008; Ashour. 2009; Soad 2010 and Dutta, et al. 2016). El-Tarabily (2004) and El-Sayed and Farrag (2011) reported that yeasts were capable to suppressed some soil-borne fungi and powdery mildew disease on sugar beet. Furthermore, Abdel-Kader et al. (2012) reported that under artificial infestation with powdery and downy mildews pathogens, Cucumber downy mildew expressed as mean diseases incidence were 54.4 and $46.6 \%$ in control, meanwhile when sprayed with ascorbic acid only or combined with Saccharonmyces cerevisiae revealed diseases infection estimated as $28.8,25.5 \%$ and 23.3 and $20.0 \%$, respectively. Ines et al. (2014) found that plants are constantly confronted to both abiotic and biotic stresses that seriously reduce productivity. Plant responses to these stresses are complex and involve numerous physiological, molecular, and cellular adaptations. Treatment with a biotic and biotic inducers activated different defense mechanisms such as accumulation of pathogenesis related protein (PR) in plant tissues (Khan, et al., 2011 and Dutta, et al. 2016 ). Also, inducers increased phenol, peroxidase and chitinase (Liang, et al., 2005 and Shafique et al., 2011).

The objective of our study was to measure the efficacy of foliar applications of Salicylic acid, Oxalic acid and yeast extract in controlling of downy mildew of cucumber. Their effect on total phenol compounds, peroxidase activity, any other probably defense mechanisms and selective plant parameters was also concerned in our aim of the study. 


\section{MATERIALS AND METHODS}

In vitro tests:

\section{Inocula preparation:}

Cucumber leaves showing natural downy mildew disease infections (Pseudoperonospora cubensis) were obtained from various cucumber cultivars grown under field condition at Etay El-Baroud, Beheria Governorate, during 2016 season. The fungus was maintained and multiplied on leaves of cucumber cultivar, Beta alpha grown in plastic pots under greenhouse conditions at Plant Pathology Research Institute, ARC, Giza, Egypt, which also served as susceptible control. Cucumber seeds of Beta alpha cultivars were planted in the pots, diameter $25 \mathrm{~cm}$ at the rate of 5 seeds per one pot. The plants were inoculated with sporangial suspension $\left(6 \times 10^{5}\right.$ sporangia/ml almost) when reached its $3^{\text {rd }}$ true leaf stage and kept under humid conditions. Sporangial suspension was sprayed onto the upper and lower surfaces of the leaves. The infected plants, 10 days after inoculation were transferred to a humid chamber $18-20^{\circ} \mathrm{C}$ overnight for inducing fungal sporulation. The sporangia were washed by shaking the detached leaves gently in sterilized distilled water for 10 minutes and filtered through four layers of cheesecloth.

\section{Effect of some resistance inducing chemicals, dry yeast, and fungicide on sporangial germination of $P$. cubensis:}

The effect of some RIC i.e., salicylic acid, oxalic acid and dry yeast as biological control compared with fungicide (Aquacid) on the sporangial germination of the fungus like $P$. cubensis was studied in vitro.

The resistance inducing chemicals (RIC) salicylic acid and oxalic acid were prepared at $0.0,5,10,25,50,75,100$ and $150 \mathrm{mM}$. Activity of bio control agent i.e., dry yeast obtained from Sigma Aldrich Chemical Co. (St. Louis, Mo, USA) $10 \mathrm{~g}$ of yeast was suspended with $100 \mathrm{~cm}^{3}$ warm water at $32^{\circ} \mathrm{C}$ followed by adding sucrose sugar at ratio $1: 1 \mathrm{w} / \mathrm{w}$ (Hibbett et.al., 2007) and kept overnight then left for three hours for activation and reproduction of yeast than used $0.0,5,10,25,50,75,100$ and $150 \%$. The concentrations of $0.0,25,50,100,150,200,300,400$ and 500 ppm. of the fungicide Aquacid (copper hydroxide) was prepared depending on the active ingredient of the fungicide. Freshly collected sporangia by sterilized brush from the infected leaves were subjected to such concentrations of the tested fungicide, RIC and dry yeast. One $\mathrm{ml}$. of sporangial suspension was placed on two sterilized slides, borne on two glass rods in a sterilized Petri-dish containing a piece of wetted cotton by sterilized distilled water to provide high relative humidity. The same was made for a spore suspension put in distilled sterilized water only as control treatment. 
Preparations were incubated in darkness at $20^{\circ} \mathrm{C}$ for 48 hour. One drop from lactophenol cotton blue stain was added at the time of slide examination to fix and killing the germinated sporangia. Percentage of sporangial germination was calculated as empty sporangium (cleared sporangium, which zoospores released out of the sporangium) in a total of 100 sporangium. The germinated sporangia were counted and mean percentage of germination was calculated and recorded for each treatment.

\section{In vivo tests:}

\section{Effect of foliar spray treatments on the activity of peroxidase and phenolic} content in cucumber plants

The effect of Aquacid, dry yeast and the RIC i.e., Salicylic acid and oxalic acid on the severity of cucumber downy mildew caused by $P$. Cubensis was carried out using artificial inoculation under greenhouse conditions Pots (25 cm in diameter) containing disinfested soil by $5 \%$ formalin were sown with Cucumber seeds. Five seeds (c.v. Beta alpha) were sown in each pot, irrigated and left to grow then thinned into two plants in each pot, 2 weeks after sowing. Five pots were used for each treatment. The grown plants (aged 3 weeks) were sprayed with the tested fungicide $(250 \mathrm{~g} / 100 \mathrm{~L}), \mathrm{RIC}$ at $150 \mathrm{mM}$ and $1500 \mathrm{mg} / \mathrm{L}$ for yeast extract five days before the artificial inoculation with sporangial suspension $\left(6 \times 10^{5}\right)$ of the pathogen. Fungicide treatment was used as positive control The plants were sprayed, RIC at $150 \mathrm{mM}$ and $1500 \mathrm{mg} / \mathrm{L}$ for yeast extract five days before the artificial inoculation with sporangial suspension $\left(6 \times 10^{5}\right)$ of the pathogen.with tested fungicide, IRC and biocontrol agent at the previous rates 15 days after the inoculation by the tested pathogen. Plants sprayed with sporangial suspension only were left as control treatment. The severity of the disease (DS) was assessed one month after spraying of the fungicide, RIC and biocontrol agent. According to Wicks and Hall, (1990). Also, plant length (cm) as well as foliage fresh weight ( $\mathrm{g} / \mathrm{plant}$ ) were assessed and taken into consideration.

Efficiency percentage was recorded weekly for five successive weeks and calculated as follows:-

Efficiency $(\%)=$ Disease severity in control - disease severity in treatment $\times 100$

\section{Disease severity in control}

\section{Field Experiments:}

Evaluation of some RIC, biocontrol agent (dry yeast) and fungicide (Aquacid) against downy mildew naturally infected cucumber was performed under field conditions at Etay El-Baroud county Beheria Governorate, during 2016 and 2017 seasons using cucumber cultivar Beta alpha which sown in the first week of March. The chemical inducers used in the study were salicylic acid and oxalic acid (150 mM). Meanwhile,Dry yeast was used (1500 mg/L). (Abou El-Yazied and Mady 2012). Plants were sprayed twice with substances under testat 15 days interval beginning after 21 days from sowing, and Aquacid $(250 \mathrm{~g} / 100 \mathrm{~L}$ ) as fungicide against downy mildew 
disease and used as positive control. The selected concentrations were mixed with adhesive surfactant (biofilm 1265 registered by Ministry of Agric., Egypt) (30 ml/100 $\mathrm{L})$ and hand homogenized before fine spraying on the upper and lower leaf surface of plants. Another set of plants were sprayed using water, which mixed with the adhesive surfactant and served as negative control treatment.

The experimental plot contained five rows ( 1.10 width $\times 3.5 \mathrm{~m}$, long). Seeds were soaked first in water for 6 hours and kept in cheesecloth for 12 hours before sowing. Seeds were planted in hills ( 2 seeds/hill) on two sides of ridges with $50 \mathrm{~cm}$ between hills. All agricultural practices were carried out according to the recommendations of the Ministry of Agriculture, Egypt. Complete randomized block design with four replicates for each treatment was used. Percentage disease severity (DS) and efficiency percentage were recorded as mentioned before in greenhouse experiments.

\section{A- Growth parameters:}

Ten cucumber plants were randomly selected from the middle part of each plot, leaving two rows from each side to avoid border effects, plant length, and number of leaves, flowers number; plant fresh weight and dry weight were recorded 75 days after sowing.

\section{B- Effect of foliar spray treatments on the activity of peroxidase and phenolic content in cucumber plants:}

Effect of resistant induced chemical i.e.,salicylic acid and oxalic acid, yeast and Aquacid fungicide on peroxidase activity and total phenolic content. In the 2nd season, the peroxidase activity and total phenol compounds were determined after three days from the second foliar spray application in second season. Leaf samples from each treatment were collected for peroxidase activity assay. Three $\mathrm{g}$ of fresh leaf were ground in a precooled mortar and pestle containing $9 \mathrm{Ml}$ of $0.1 \mathrm{M}$ phosphate buffer ( $\mathrm{pH}$ 7.1). The extract was centrifuged at $3000 \mathrm{rpm}$ at $6 \mathrm{C}^{\circ}$ for $20 \mathrm{~min}$. Peroxidase activity was expressed as changes in absorbance 1- min at $425 \mathrm{~nm}$, according to the methods mentioned by Allam and Hollis (1972).

Total phenol in fresh leaves extract was determined using the colorimetric method described by Folin and Ciocalteu (AOAC, 1985). standard curve from a pure chemical of catechol was used.

\section{Statistical analysis:}

Analysis of variance was carried out using MSTAT-C (1991) program version, least significant difference (LSD) was employed to score significant different between treatment at $\mathrm{P} \leq 0.05 \%$ (Gomez and Gomez, 1984). 


\section{RESULTS}

\section{In vitro testes:}

Effect of some resistance inducing chemicals, dry yeast, and fungicide on sporangial germination of $\boldsymbol{P}$. cubensis:

Data presented in Table (1) reveal that the tested RIC, dry yeast as biological control agent and Aquacid as fungicide caused significant reduction in the germination percentage of sporangia compared to the control treatment. Aquacid was the most efficient one, being $28.8 \%$ sporangial germination in the average and caused $0.0 \%$ inhibition of germination to the sporangia treated with $500 \mathrm{ppm}$ followed by dry yeast, and Salicylic acid which gave $48.3 \%$ and $52.3 \%$ respectively,for sporangial germination. Oxalic acid caused, the least significant effect on sporangial germination,being $59.8 \%$. The inhibitory effect to the sporangial germination was gradually increased by increasing the RIC, dry yeast and fungicide concentration. Control treatment recorded $94.5 \%$ for sporangial germination.

Table 1. Effect of some inducer resistance chemicals, dry yeast, and fungicide on sporangial germination of $P$. cubensis.

\begin{tabular}{|c|c|c|c|c|c|c|c|c|c|}
\hline \multirow{2}{*}{ Treatment } & \multicolumn{10}{|c|}{ Average percentage of sporangial germination at (mM.) and /or mg//\% } \\
\cline { 2 - 11 } & 5 & 10 & 25 & 50 & 75 & 100 & 125 & 150 & Mean \\
\hline Salicylic acid & 81.1 & 75.4 & 68.1 & 59.3 & 49.0 & 38.7 & 28.3 & 19.1 & 52.3 \\
\hline Oxalic acid & 84.2 & 80.4 & 74.5 & 67.3 & 58.5 & 48.6 & 37.2 & 27.8 & 59.8 \\
\hline Dry yeast & 80.3 & 74.3 & 67.7 & 57.4 & 48.2 & 35.3 & 20.4 & 3.2 & 48.3 \\
\hline & \multicolumn{10}{|c|}{ Average percentage of sporangial germination at (ppm) } \\
\hline Fungicide & \multicolumn{10}{|c|}{} \\
\cline { 2 - 11 } & 25 & 50 & 100 & 150 & 200 & 300 & 400 & 500 & Mean \\
\hline Aquacid & 72.1 & 60.5 & 43.7 & 27.3 & 16.3 & 8.1 & 2.0 & 0.0 & 28.8 \\
\hline Control & 94.5 & 94.5 & 94.5 & 94.5 & 94.5 & 94.5 & 94.5 & 94.5 & 94.5 \\
\hline
\end{tabular}

L.S.D. at $5 \%$ for treatments $(T)=2.2$, Concentration $(C)=2.9$ and $T x C=3.7$

\section{In vivo testes:}

\section{Greenhouse experiment:}

Results figured in Table (2) clearly demonstrated that all the tested fungicide, RIC and bioagent resulted in significant reduction in the downy mildew severity as well as significant increases in the plant length and foliage fresh weight of cucumber plants as compared with control treatment.

However, the tested fungicide, i.e. Aquacid, was more efficient in this regard, as it reduced with significant increases in plant length $(103.4 \mathrm{~cm})$ and foliage fresh weight (194.5g) whereas, those of RIC, i.e. salicylic acid and oxalic acid, reduced disease severity to be 9.0 and $10.8 \%$, and Dry yeast ranked the third in this regard, to 7.6 as it reduced disease severity. 
Table 2. Effect of spraying with to induced resistant chemicals, bioagent and fungicide, on the disease severity of cucumber downy mildew as well as plant length and foliage fresh weight under greenhouse conditions.

\begin{tabular}{|c|c|c|c|c|}
\hline Treatment & $\begin{array}{c}\text { Disease } \\
\text { Severity\% }\end{array}$ & Efficiency (\%) & $\begin{array}{c}\text { Average plant } \\
\text { length (cm) }\end{array}$ & $\begin{array}{c}\text { Average foliage fresh } \\
\text { weight (g) / plant }\end{array}$ \\
\hline $\begin{array}{c}\text { Aquacid } \\
250 \mathrm{~g} / 100 \mathrm{~L}\end{array}$ & 2.3 & 94.85 & 103.4 & 194.5 \\
\hline $\begin{array}{c}\text { Salicylic acid } \\
150 \mathrm{mM}\end{array}$ & 9.0 & 79.86 & 97.3 & 190.2 \\
\hline $\begin{array}{c}\text { Oxalic acid } \\
150 \mathrm{mM}\end{array}$ & 10.8 & 75.83 & 96.3 & 192.1 \\
\hline $\begin{array}{c}\text { Dry yeast } \\
1500 \mathrm{mg} / \mathrm{L}\end{array}$ & 7.6 & 82.99 & 99.2 & 132.4 \\
\hline Control & 44.7 & ---- & 45.4 & 2.9 \\
\hline L.S.D at 5\% & 3.1 & & 2.8 & \\
\hline
\end{tabular}

\section{Field experiment:}

The efficacy of foliar spray application with two induced plant resistant chemicals i.e. Salicylic acid, and Oxalic acid as well as biocontrol agent yeast extract in addition to the fungicide Aquacid as a comparison treatment, on downy mildew disease severity on cucumber plants was evaluated under field conditions.

Obtained results presented in Table (3) revealed that all applied treatments have positive effect in decreasing downy mildew disease severity as compared tocontrol. Fungicide Aquacid $(2.5 \mathrm{~g} / \mathrm{L})$ and yeast extract $(150 \mathrm{~g} / \mathrm{L})$ reduced disease severity with the averages of 7.25 and 16.40 respectively followed by Salicylic acid and Oxalic acid $(150 \mathrm{mM})$ with averages of 25.43 and $30.00 \%$, respectively. The same trend was cleared with the data obtained in the second season.

Table 3. Effect of foliar application with Salicylic acid, Oxalic acid, yeast extract and Aquacid on disease severity of cucumber downy mildew at grown at two seasons (2016 and 2017).

\begin{tabular}{|c|c|c|c|c|}
\hline \multirow{2}{*}{ Treatment } & \multicolumn{3}{|c|}{ downy mildew disease severity } & Efficiency (\%) \\
\cline { 2 - 5 } & $\begin{array}{c}\text { 1st season } \\
(2016)\end{array}$ & Efficiency (\%) & $\begin{array}{c}\text { 2nd season } \\
(2017)\end{array}$ & 48.06 \\
\hline $\begin{array}{c}\text { Salicylic acid } \\
150 \mathrm{mM}\end{array}$ & 25.43 & 50.86 & 24.15 & 45.27 \\
\hline $\begin{array}{c}\text { Oxalic acid } \\
150 \mathrm{mM}\end{array}$ & 30.00 & 42.03 & 25.45 & 71.33 \\
\hline $\begin{array}{c}\text { Dry yeast } \\
1500 \mathrm{mg} / \mathrm{L}\end{array}$ & 16.40 & 68.31 & 13.33 & 86.02 \\
\hline $\begin{array}{c}\text { Aquacid } \\
250 \mathrm{~g} / 100 \mathrm{~L}\end{array}$ & 7.25 & 85.99 & 6.50 & - \\
\hline Control & 51.75 & - & 46.50 & \\
\hline LSD at 5\% & 2.11 & & 3.331 & \\
\hline
\end{tabular}


Data given in Table (4) indicatethat spraying plants by Salicylic acid, Oxalic acid, yeast extract and, Aquacid significantly increased all growth parameters studied including plant length, number of leaves, number of flowers, fresh and dry weight of cucumber plants. Generally, application of the tested substances led to significant differences between them in both seasons. In the first season, the highest value of plant length was found in case of plant treated with fungicide (Aquacid) with an average of $98.75 \mathrm{~cm}$. In this respect, application with yeast extract came in the top of tested treatments followed by the treatments of Salicylic acid and Oxalic acid with the averages of $92.75,81.00$ and $74.0 \mathrm{~cm}$, respectively. In the second season, Aquacid, yeast suspension, Salicylic acid and Oxalic acid increased plant length with averages of $110.5,107.3,98.5$ and $90.0 \mathrm{~cm}$, respectively. Number of leaves plant significantly increased in plant sprayed with Aquacid, yeast suspension, followed by Salicylic acid, and Oxalic acid with the averages of 43.3, 39.5, 30.0 and 24.5 leaves, respectively. Similar results were obtained in the second season. Also, the number of flowers per plant was recorded and the highest value obtained with the fungicide followed by the treatment of yeast extract Salicylic acid and Oxalic acid with the averages of 22.0,10.75, 10.50 and 7.50 flower, respectively.. In the second season, Aquacid, yeast extract Salicylic acid, and Oxalic acid increased number of flowers and their averages were 29.75, 18.5, 10.0 and 8.5 flower, respectively. Generally, fresh weight of plants was increased significantly in plants sprayed with Aquacid, yeast extract, Salicylic acid and Oxalic acid. In the first season, the best results were obtained with Aquacid, and yeast extract with averages of 153.3 , and $103.5 \mathrm{~g}$, respectively. On the other hand, the lowest values were obtained with Salicylic acid, and Oxalic acid, being 75.0 and $55.5 \mathrm{~g}$, respectivelyin the average. In the second season significant increases were cleared in plants sprayed with Aquacid, yeast suspension, Salicylic acid, and Oxalic acid with averages of $195.0,166.5,81.5$ and $72.5 \mathrm{~g}$, respectively. Dry weight of cucumber plants was also significantly differed according to variable treatments. However, Aquacid and yeast extract resulted the highest shoot dry weight at both seasons (18.52, 11.63, 23.58, and $17.65 \mathrm{~g})$, respectively, followed by Salicylic acid and Oxalic acid treatments at both seasons (8.52, 7.18, 10.48 and $9.48 \mathrm{~g}$ ) respectively. 
Table 4. Effect of foliar application with Salicylic acid, Oxalic acid, yeast extract and Aquacid on some growth parameters of cucumber plants at two grown seasons 2016 and 2017.

\begin{tabular}{|c|c|c|c|c|c|c|c|c|c|c|}
\hline \multirow[b]{2}{*}{ Treatment } & \multicolumn{5}{|c|}{ 1st season } & \multicolumn{5}{|c|}{ 2nd season } \\
\hline & 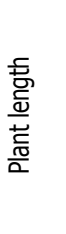 & 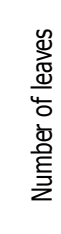 & 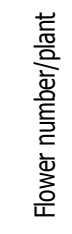 & 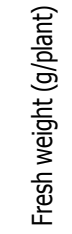 & 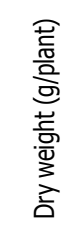 & 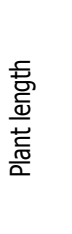 & 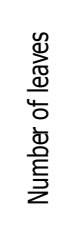 & 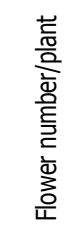 & 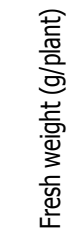 & 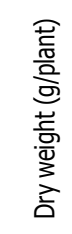 \\
\hline $\begin{array}{c}\text { Salicylic acid } \\
150 \mathrm{mM}\end{array}$ & 81.00 & 30.0 & 10.50 & 75.0 & 8.52 & 98.50 & 31.5 & 10.00 & 81.50 & 10.27 \\
\hline $\begin{array}{c}\text { Oxalic acid } \\
150 \mathrm{mM}\end{array}$ & 74.00 & 24.5 & 7.50 & 55.5 & 7.18 & 90.00 & 27.0 & 8.50 & 72.50 & 9.48 \\
\hline $\begin{array}{l}\text { Dry yeast } \\
1500 \mathrm{mg} / \mathrm{L}\end{array}$ & 92.75 & 39.5 & 10.75 & 103.5 & 11.63 & 107.3 & 42.8 & 18.50 & 166.50 & 17.65 \\
\hline $\begin{array}{c}\text { Aquacid } \\
250 \mathrm{~g} / 100 \mathrm{~L}\end{array}$ & 98.75 & 43.3 & 22.00 & 153.3 & 18.52 & 110.5 & 50.0 & 29.75 & 195.00 & 23.58 \\
\hline Control & 51.50 & 10.8 & 4.00 & 21.5 & 3.45 & 63.5 & 13.3 & 50.30 & 31.30 & 4.61 \\
\hline LSD at $5 \%$ & 5.96 & 3.03 & 2.12 & 7.99 & 2.78 & 9.91 & 3.20 & 2.16 & 11.31 & 2.88 \\
\hline
\end{tabular}

\section{Effect of foliar spray treatments on the activity of peroxidase and phenolic content in cucumber plants:}

Data in Table (5) indicate that all applied treatments of Salicylic acid, Oxalic acid, yeast extract, and Aquacid significantly increased peroxidase activity (PO) and total phenolic content in cucumber leaves under open field conditions compared with control. In addition, foliar treatments with, Salicylic acid, yeast extract and Aquacid recorded the highest increase in PO activity compared to other treatments with the averages of $0.624,0.573$ and 0.570 , respectively followed by Oxalic acid with an average of 0.486 .Concerning with the amount of total phenolic content, data in table (5) declare that Salicylic acid and yeast extract caused significant increase in total phenolics, followed by Aquacid and Oxalic acid with averages of $0.625,0.614,0.587$ and $0.427, \mathrm{mg} / \mathrm{g}$ fresh weight of leaves respectively. 
Table 5. Peroxidase activity and total phenolic contents in cucumber plants grown after foliar application with Salicylic acid, Oxalic acid, yeast extract and Aquacid at the 2nd season 2017.

\begin{tabular}{|c|c|c|}
\hline Treatment & Peroxidase activity* & $\begin{array}{c}\text { Total phenolic content } \\
\text { (mg/g fresh weight of leaves) }\end{array}$ \\
\hline $\begin{array}{c}\text { Salicylic acid } \\
150 \mathrm{mM}\end{array}$ & 0.624 & 0.625 \\
\hline $\begin{array}{c}\text { Oxalic acid } \\
150 \mathrm{mM}\end{array}$ & 0.486 & 0.427 \\
\hline $\begin{array}{c}\text { Dry yeast } \\
\text { 1500mg/L }\end{array}$ & 0.573 & 0.614 \\
\hline $\begin{array}{c}\text { Aquacid } \\
250 \mathrm{~g} / 100 \mathrm{~L}\end{array}$ & 0.570 & 0.587 \\
\hline Control & & 0.203 \\
\hline
\end{tabular}

$*$ Peroxides activity expressed as change in absorbance at $425 \mathrm{~nm} / \mathrm{g}$ fresh weight $/ 20 \mathrm{~min}$.

Figure $(1,2)$ and data in Table (6) indicate that all foliar treatments with inducers resistance recorded the lowest percentage of disease severity (DS) of downy mildew on cucumber plants. In addition, negative linear relationship between the reduction in DS of downy mildew and PO and total phenol contents was increased. Regression analysis shows that PO activity compounds contribute to about 70.6\% (R2 $=0.706, \mathrm{P}>0.005)$ and total phenol contents76.1\% $(\mathrm{R} 2=0.761, \mathrm{P}>0.005)$.

(A)

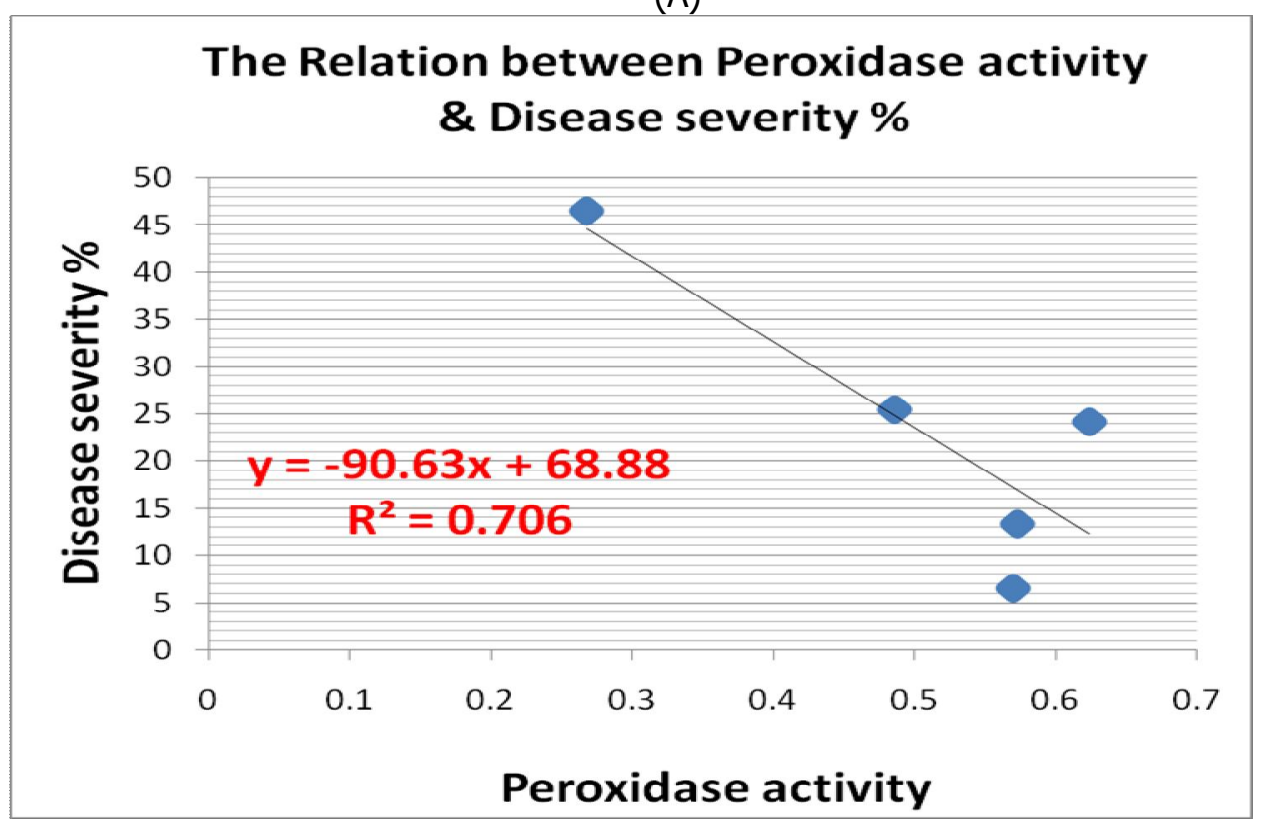

Fig. 1 
(B)

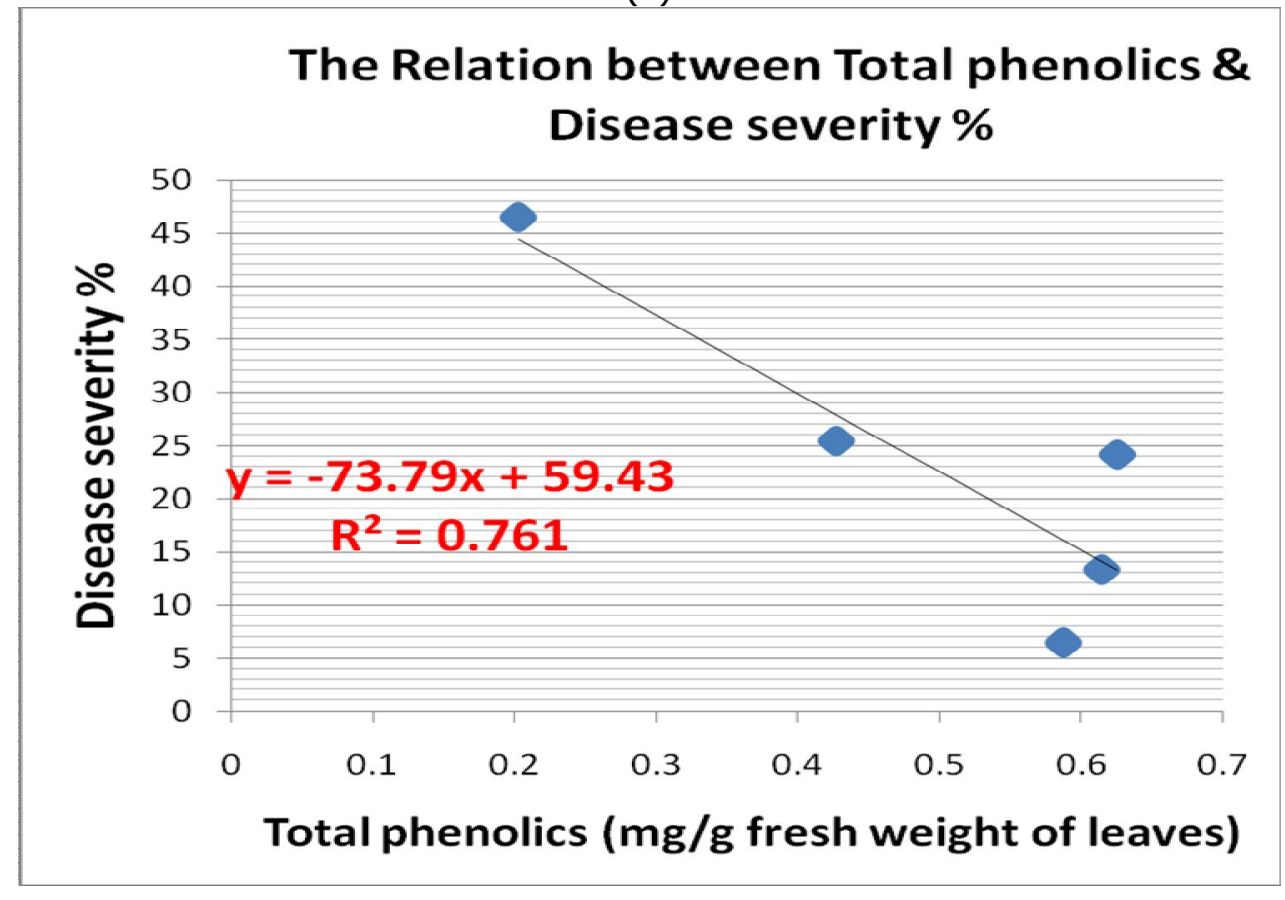

Fig. 2

Fig 1 and Fig 2 : Relationship between disease severity of downy mildew and each of peroxidase activity (A) and total phenol contents (B) as $\mathrm{mg} / \mathrm{g}$ of cucumber plants sprayed with Salicylic acid, Oxalic acid, yeast extract, and Aquacid in the 2nd season 2017.

Table 6. Correlation coefficient between disease severity \% and each of Peroxidase activity and Total phenol contents

\begin{tabular}{|c|c|c|c|c|}
\hline Variable & $\begin{array}{c}\text { Regression } \\
\text { equation }\end{array}$ & $\begin{array}{c}\text { Regression coefficient } \\
\text { (r2) }\end{array}$ & $\begin{array}{c}\text { Correlation } \\
\text { coefficient } \\
(\mathbf{r}) * *\end{array}$ & F. value \\
\hline $\begin{array}{c}\text { Peroxidase } \\
\text { activity }\end{array}$ & $\mathrm{Y}=-90.63 \mathrm{X} 1+$ & 0.706 & 0.840 & 7.210 \\
\hline $\begin{array}{c}\text { Total phenolic } \\
\text { content }\end{array}$ & $\begin{array}{c}\mathrm{Y}=-73.88 \\
59.43 \times 2+\end{array}$ & 0.761 & 0.872 & 9.566 \\
\hline $\begin{array}{c}\text { Interaction } \\
\mathbf{X 1 + X 2}\end{array}$ & $\begin{array}{c}\mathrm{Y}=78.828 \mathrm{X} 1- \\
134.752 \mathrm{X} 2+ \\
49.631\end{array}$ & 0.775949 & 0.881 & 3.463 \\
\hline
\end{tabular}

All correlations are significant at the $\mathrm{p}>0.005(* * *)$.

\section{DISCUSSION}

Nowadays, world-wide as well as developing countries are suffering from environmental pollution caused by a number of pollutants among those are plant pesticides. Hence, recent strategies for pest control managements concentrated on the use of such alternative safe methods rather than those of chemical pesticide methods especially for the control of vegetable and fruit crops diseases. It was also recommended to apply such chemicals at the first stage of plant growth prior to fruit 
maturity to give such chance to chemical compounds to depredate to a safe degree before harvest. Cucumber plants are liable to the infection by many fungal diseases; however, downy mildew caused by the fungus Pseudopersonospora cubensis is the most intended concerned one. It is an Oomycetes fungi more closely related to water molds such as phytophthora than to true fungi. The peak of infection reaches its maximum at the time of fruit maturity and harvesting (Colucci, 2008 and Muhammad et al. 2014). There are multiple path types of $P$. cubensis; watermelons, pumpkins, and squash are incompatible with several pathotypes, while cucumbers and cantaloupe are susceptible to them all. There are also several strains within each pathotype, to which various cultivars of each type of cucurbit show varying degrees of susceptibility. P. cubensis can survive and sporulate only on green (living) tissue of the host (Zitter, et al., 1996).This research study aimed to test and use safe chemicals as RIC, bioagent in alteration with fungicide, where the fungicide spray applied at the first period of infection (before fruit maturity) to lowering the infection by the disease for the time of fruit formation until pre-maturity. Then spraying the RIC and the bioagent before and during harvesting the fruits were carred out in order to harvest fruits free or low fungicide residue and / or of permitted ratio, which are of safe consumption and of high price. In vitro experimental results showed that the tested fungicide, i.e. Aquacid, RIC, i.e. salicylic acid and oxalic acid and the bioagent, i.e. Dry yeast highly inhibited sporangial germination of $P$. cubensis compared with the control, These results are in harmony with those obtained by many researches) (Reglinski et al., 1994 and Yan-xingfu et al., 1997). In facts, fungicide treatment shoued more efficient than other treatmants . as aresult of the well-known inhibitory effect of the fungicide on the tested fungus $P$. cubensis because of the fungicidal effect on the fungal cell wall. In addition, similar results were obtained by Muhammad et al. (2014). Pot experiment data revealed that the tested fungicide Aquacid, RIC i.e. salicylic acid and oxalic acid, and the Dry yeast bioagent resulted in significantly reduction to cucumber downy mildew disease with significant increase to plant length and foliage fresh weight compared with control treatment. On the other hand, fungicide was more efficient than RIC and bioagent in this regard. These results are in harmony with those obtained by many researches Abdel - Kader et al. (2012). Thy found that plant sprayed with chemical inducers and $S$. cerevisiae under plastic house conditions, significantly reduced disease incidence of powdery and downy mildews on cucumber, cantaloupe and pepper plants. The role of RIC could be explained by many hypothesis, where induced acquired resistance was induced by restricted infection is not due to a specific component of the pathogen, but rather to gradual appearance and persistence of a level of metabolic perturbation leading to stress on the host. Also, RIC were reported as alternative and or safe trial for management of many 
diseases, especially those of vegetable crops (Metranx and Boller, 1986; Abo-Taleb, 2001; Hilal, 2004; Muhanna, 2006; Abada et al., 2008; Ashour, 2009 and Abada ;Abdel- Malek, 2011 and Dutta, et al. 2016). Doubrava et al., (1988) mentioned that induced acquired resistance is persistent and generally is pathogen nonspecific. Larcke (1981) found that unlike elicitors of phytoalexins accumulations, which are elicited at the site of application, may be responsible for localized protection and induces systemic acquired resistance that sensitizes the plant response rapidly after infection. These responses induced phytoalexins accumulation and lignifications and induce enhance activities of chitinase and P-glucanase (Dean and Kuc, 1985 and Metranx ; Boller, 1986 and Dutta, et al. 2016 ). Furthermore, kessmann et al. (1994) reported that the mechanism of resistance inducering chemicals is apparently multifaced, likely resulting in stable broad spectrum disease control and they could be used preventatively to bolster general plant health, resulting in long lasting protection. Also, in this regard, yeast extract reduced downy mildew incidence in cucumber plants. In addition, Nadia (2003) reported that applied yeast $S$. cerevisiae on cucumber plants reduced the disease severity of powdery mildew with an average of $41.7 \%$ compared with the control. The mode of action of yeast $S$. cerevisiae was observed on sugar beet surfaces by scanning electron microscopy, completely malformation, and lyses of Erysiphe betae hyphe with highly yeast colonization was found (El-Sayed and Eman, 2011). Chemical control is highly recommended because downy mildew is an aggressive and destructive disease and satisfactory control without the use of fungicides is unlikely. The role of fungicides in reducing the disease is well known (Mc Grath, 2001and Muhammad et al.2015 ). It is well known that fungicides, especially systemic ones are more efficient in management of many fungal diseases including downy mildew (Mc Grath, 2001; Gisi, 2002; Ashour, 2009 ; Muhammad et al.2016 and Sujoy et al. 2017). In field experiments, foliar application with fungicide Aquacid $(2.5 \mathrm{~g} / \mathrm{L})$ as a comparison treatment, Salicylic acid, Oxalic acid, and yeast extract in concern, significantly reduced the disease severity of downy mildew with the averages of $7.25,25.43,30.0$ and $16.40 \%$, respectively compared with untreated plants in the first season 2016. The same trend was cleared in the second season 2017 with the averages of $6.50,24.15,25.45$ and $13.33 \%$, respectively. Moreover, the treatments in concern significantly increased all of the studied growth parameters, i.e. plant length, leaves number, number of flowers, fresh and dry weight/plant. These findings are in agreement with the results of El -Tohamy et al. (2008) who found that foliar application of yeast extract and ascorbic acid increased vegetative growth of eggplant. Also, Abou El-Yazied and Mady (2012) reported that yeast extract stimulated growth of broad bean and increased amino acid, auxins and cytockinins 75 days after sowing 
of broad bean. Similar results on the stimulatory effect of vitamin $C$ and dry yeast were indicated on garlic (Shalaby and El-Ramady 2014). Treatments showed remarkable increase in physiological aspects (Peroxidase activity and total phenol content), similar reduction in disease severity of downy mildew revealed the most superior positively correlated with both peroxidase activity $(R 2=70.6, P>0.005)$ and total phenol content ( $R 2=76.1, P>0.005)$. In this regard, increasing activity of (PO) in plants treated with various treatments was recorded by some investigators, Cai et al., 2008). Taqi et al. (2011) showed that ascorbic acid regulated stress response as a result of a complex sequence of biochemical reaction such as activation or suppression of key enzymatic reaction, induction of stress responsive protein synthesis, and the production of various chemical defense compounds. They also total phenolics significantly increased at treatments of Geranium (Pelargium graveolens L.) foliar sprayed with salicylic acid, riboflavin and dry yeast, (Safaa et al., 2011). Furthermore, El-Khallal (2007) reported that both polyphenol oxidase and peroxidase are important in the defence mechanism against pathogens, through their role in the oxidation of phenolic compounds to quinines, causing increase in antimicrobial activity. Therefore, they may be directly involved in stopping pathogen development accelerating the cellular death of cells close to the infection site, preventing the advance of infection and / or by generating a toxic environment which will inhibit the growth of the pathogen inside the cells.Our results suggested that, beside the ability of the previous agent to induce resistance in many plants against pathogens they could be used as protect treatments. Most of elicitors are, available. They are easy to use as environmentally safe. They are used through integrated pest managements.

\section{REFERENCES}

1. Abada, K.A. and A.M. Abdel- Malek, Gehan. 2011. The role of some systemic fungicides and resistance inducing chemicals in controlling pea downy mildew. Zagazig J. Agric. Res., 38 (2) : 319-337.

2. Abada, K.A., R. Mervat Hilal and S.H. Mostafa. 2008. Induced resistance against powdery mildew in cucumber. J. Biol. Chem. Environ. Sci., 3 (3): 45-56.

3. Abdel-Kader, M.M.; N.S. El-Mougy; M.D.E. Aly and S.M. Lashin. 2012. Integration of biological and fungicidal alternatives for controlling foliar diseases of vegetables under greenhouse conditions. International Journal of Agriculture and Forestry, 2: 38-48.

4. Abo- Taleb, Mona, M.A. 2001. Biochemical changes associated with application of some resistance inducing compounds for controlling powdery mildew of cucumber, Egypt. J. Appl. Sci., 16 (14): 387-404.

5. Abou El-Yazied, A and Mady M.A. 2012. Effect of boron and yeast extract foliar 
application on growth, pod setting and both green and seed yield of broad bean (Vicia faba L.). I. Amer. Sci., 8: 517-534.

6. Allam, A.I. and S.P. Hollis. 1972. Sulfide inhibition of oxidase in rice root. Phytopathology, 62: 634-639.

7. Ashour, A.M.A. 2009. Effect of application of some fungicides and resistance inducing chemicals on management of cantaloupe powdry mildew. Egypt. J.Phytopathol., 37 (1) : 1-8.

8. Cai, K.; D. Gao; S. Luo; R. Zeng; J. Yang and X. Zhu. 2008. Physiological and cytological mechanisms of silicon-induced resistance in rice against blast disease. Phsiologia Plantarum 134: 324-333.

9. Chiu, P. H.; J. W. Huang. 2014. Control experiments of cucumber downy mildew with emulsified plant oils. Plant Pathology Bulletin; 23(3/4):277-283.

10. Colucci, S. 2008. Host range, fungicide resistance and management of Pseudoperonospora cubensis, causal agent of cucurbit downy mildew. M.Sc. thesis, North Carolina State Univ.

11. Daubrava, N.; R. Dean and J. Kuc. 1988. Induction of systemic resistance to anthracnose caused by colletetrichum lagenarum from spinash and hubar leaves. Physiol. Mol. Plant pathol., 33: 60-70.

12. Dean, R.A. and J. Kuc. 1985. Induced systemic protection in plants. Trends biotechnol. 23 : 125-128.

13. Dutta,S.; P. P.Ghosh,; B. A. Roy,; S. P. Kuiry,; S.Hembram, and A. Chattopadhyay. 2016. Efficacy of fungicides and inducer molecule for management of downy mildew of cucumber under trellis/non-trellis system of cultivation. Annals of Plant Protection Sciences; 24(1):118-122.

14. El-Gamal, N.G.; F. Abd-El-Kareem,; Y.O. Fotouh, and N.S. El-Mougy. 2007. Induction of systemic resistance in potato plants under late and early blight diseases using chemical inducers under greenhouse and field conditions. Research Journal of Agriculture and Biological Sciences, 3(2): 73-81,

15. El-Helaly, A.F.; I.A. Ibrahim; M.W. Assawah; H.M. Elarosi; M.K. Abou El-Dahab; S.N. Michail and A.M. Abd EL-Rahim. 1963. General survey of plant diseases and pathogenic organisms in the United Arab Republic (Egypt) until (1962): Res. Bull, Fac. Agric., Alexandria Univ.

16. El- Khallal, Samia M., 2007. Induction and modulat of resistance in tomato plants against fusarium wilt disease by bioagent fungi (arbuscular mycorrhiza) and / or hormonal elicitors (jasmonic acid 6 salicylic acid) : 2- changes in the antioxidant enzymes, phenolic compounds and pathogen related - proteins. Australian journal of Basic and Applied Sciences, 1 (4) : 717-732. 
17. El-Nagar, M.A.A.; F.M. Maklad; M.H. Ali and F.A. Fadi. 1991. Downy mildew disease of cucumber in plastichouses and its control. Egypt. J. Appl. Sci.,

18. El-Sayed, H.E.Z. and Eman S.H. F. 2011. Application of yeast as biocontrol agents for controlling foliar diseases on sugar beet plants. Journal of Agricultural Technology, 7: 1789-1788.

19. El-Sayed, H.E.Z. and E S.H. Farrag. 2011. Application of yeast as biocontrol agents for controlling foliar diseases on sugar beet plants. Journal of Agriculture Technology, 7: 1789-1799.

20. El-Tarabily, K.A. 2004. Suppression of Rhizoctonia solani diseases of sugar beet by antagonistic and plant growth-promoting yeasts. J. Appl. Microbiol. 96: 69-75.

21. El-Tohamy, W.A.; H.M. El-Abagy and N.H.M. El-Greadly. 2008. Studies on the effect of putrescine, yeast and vitamin $C$ on growth, yield and physiological responses of eggplant (Solanum melongena L.) under sandy soil condition. Australian Journal of Basic and Applied Sciences, 2(2): 296-300,

22. Folin and Ciocalteu (AOAC) 1985. Official methods of analysis, 12th ed. Washington, D.C., PP. 376-384.

23. Advances in Downy Mildew Research, 119-159. (c) 2002 Kluwer Academic Publishers. Printed in the Netherlands.

24. Gisi, U. 2002. Chemical control of downy mildews. advances in downy mildew research Kluwer Academic Publishers. Printed in the Netherlands. 119-159. (P.T.N. )

25. Gomez, K.A. and A.A. Gomez. 1984. Statistical procedures for agricultural research. A. Lviley. Interscience Publication. New York, pp: 678.

26. Gullino, M.L.; R. Albajes and J.C.V. Lenteren. 1999. Setting the stage: characteristics of protected cultivation and tools for sustainable crop protection. In: Integrated Pest and Disease Management in Greenhouse Crops, eds. R. Albajes, M.L. Gullino,J.C. van Lenteren and Y. Elad, pp. 1-13. The Netherlands: Kluwer.

27. Hibbett, D. S., M. Binder, J. F. Bischoff, M. Blackwell, P. F. Cannon, O. V. Eriksson. 2007. "A higher-level phylogenetic classification of the fungi " Mycological Research, vol. 111, pp. 509-547

28. Hilal, Mervat. R. 2004. Induced acquired resistance to cantaloupe powdery mildew by some chemicals under greenhouse conditions. Egypt. J. Appl. Sci., 19 (1): 82-90.

29. Ines, B.R.; P. Victoria and M. Brigitte. 2014. Plant responses to simultaneous biotic and abiotic stress: molecular mechanisms. Plants - ISSN 2223-7747. 3: 458- 474. 
30. Kessmann, H., T. Sataub, C, H of mann, T. Meafzke and J. Herzog. 1994. Induction of systemic acquired disease resistance in plants by chemicals Ann. Rev. phytopathol., 32 : 439-459.

31. Khan, T.A.; M. Mazid and F. Mohammad. 2011. Role of ascorbic acid against pathogenesis in plants. Journal of Stress Physiology \&Biochemistry 7: 223- 234

32. Larcke, P. 1981. Alternative chemical agents for controlling plant diseases. Phil. Trans. Res. Soc., 2: 83-101.

33. Liang, Y.C.; W.C. Sun; W.C. Si and V. Romheld 2005. Effect of foliar - and rootapplied silicon on the enhancement of induced resistance to powdery mildew in Cucumis sativus. Plant Pathology 54: 678-685.

34. Mc. Grath, Margret, T. 2001. Fungicide resistance in cucurbit powdery mildew. Plant Dis., 85 (3): 236-250.

35. Metranx, J.D. and T. Boller. 1986. Local and systemic induction of chitinase in cucumber plants in response to fungal, bacterial and viral infections. Physiol Mol. Pathol., 28 : 161-169.

36. Muhanna, Naglaa A.S., 2006. Pathological studies on root- rot and vine decline of cantaloupe in Egypt. Ph.D. thesis, Fac. Agric., Cairo Univ., pp : 218.

37. Muhammad Waris; Imran-ul-Haq; Khan, S. A.; Farooq Ahmad; Mudassir Iqbal; Muhammad Shoaib; Zia Ullah(2014). Screening of cucumber varieties against downy mildew (Pseudoperonospora cubensis) and its chemical management. Pakistan Journal of Phytopathology; 26(1):21-24.

38. Muhammad Nasir; Babar Iqbal; Muhammad Sajjad; Muhammad Idrees; Ghulam Mohy-Ud-Dina; Iqra; Khan, W. A.; Abdul Hannan. 2015. Effectiveness of new fungicides against cucumber downy mildew under tunnel conditions. Pakistan Journal of Phytopathology; 27(2):175-179.

39. Muhammad Nasir; Babar Iqbal; Muhammad Saqib; Muhammad Sajjad; Niaz, M. Z.; Muhammad Idrees; Waseem Abbas; Ghulam Mohy-ud-Din. 2016. Evaluation and standardization of fungicides against plant diseases in Punjab-Pakistan crop production system. Journal of Agricultural Research (Lahore); 54(2):233-249.

40. Nadia G. El-Gamal. 2003. Usage of some biotic and abiotic agents for inducing of resistance to cucumber powdery mildew under plastic house conditions. Egypt J. Phytopathol., 31: 129-140.

41. Reglinski, T.; A.C. Newton and G. Lyon. 1994. Assessment of the ability of yeastderived resistance elicitors to control barley powdery mildew in field. J. Plant Dis. and Protect., 101: 1-10.

42. Safaa, E.; H.S. Ayad and F. Reda. 2011. Effect of riboflavin, ascorbic acid and dry 
yeast on vegetative growth, essential oil pattern and antioxidant activity of Geranium (Pelargonium graveolens L.). American - Eurasian J. Agric \& Environ. Sci., 10: 781-786.

43. Shafique, S.; T. Anjum; S.Shafique; A. Ahmad; W. Akram and Z. Bashir. 2011. Induction of systemic defenses in plant under the activity of dynamic inducers. Mycopathology. 9: 95-104.

44. Shalaby, A.S. and H. El-Ramady. 2014. Effect of foliar application of bio-stimulats on growth, yield, component, and storability of garlic (Allium sativum L.). Australia Journal of Crop Science. 8: 217: 275.

45. Shama, S.M., M.A. Amer and M.A. El-Farnawany, 1998. Greenhouse evaluation of adjutants for effective control of downy mildew (Pseudoperonospora cubensis) of cucumber (Cucumis sativus L.) with fungicides. Crop Protec., 63: 1057-1066.

46. Soad M. Ahmed. 2010. Effect of salicylic acid, ascorbic acid and two fungicides in control of blight disease and some physiological components of two verities of potatos. J. Agric. Res. Kafer El-Shiekh Univ., 36 (2): 220-237.

47. Spencer, D.M. 1981. The Downy Mildew. Acad. Press London, Brace Jovanovich Publishers. 636. pp.

48. Sujoy Saha; N. D. Ashtekar,; A. B. Rai,; B. K. Sharma,; A. K. Balaraman, 2017. Synergistic effect of Benalaxyl 8\% and Mancozeb 65\% WP in combating downy mildew of cucumber. Journal of Mycopathological Research; 55(3):227-230.

49. Taqi A.K.; M. Mohd and M. Firoz. 2011. Role of ascorbic acid against pathogenesis in plants. Journal of Stress Physiology\&Biochemistry. 7: 223-234.

50. Varary, C. and Y. Ducrat. 1989. Downy mildew of cucumber. Revue Suisse de Virticulture, d Avboriculture at d Horticulture, 17 (2): 103-106. (c.f. R.P.P., 64: (9) 404.

51. Wicks, T. and B. Hall. 1990. Efficacy of dimethomorph against downy mildew of grape vines. Plant Dis., 74 (2):114-116.

52. Yan Xingfu; Li Rong Xi; Ma Liguo and Huo Xiuwen. 1997. Induced resistance to downy mildew in cucumber by chemicals. Acta Phytophylacica Sinica, 24 (2):159-163.

53. Zitter, T.A., D.L. Hopkins and C.E. Thomas. 1996. Compendium of cucurbit Diseases. APS press, st. paul, Mn. Pp : 87. 


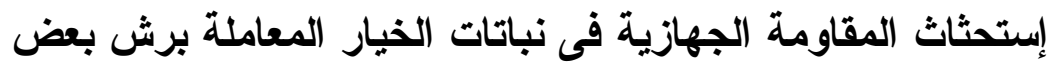

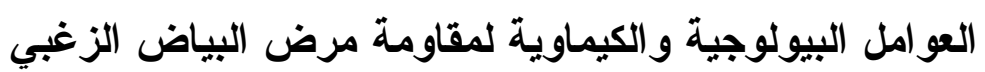

محمد عفت خليل إبراهيم وعصام محمد عبد الوهاب عشماوي

قسم بحوث المكافحة المتكاملة - معهد بحوث أمراض النباتات - مركز البحوث الزراعية - الجيزة

تم أختبار تأثير كلاً من بعض المستحثات الكميائية منل حامض السلسيلك وحامض

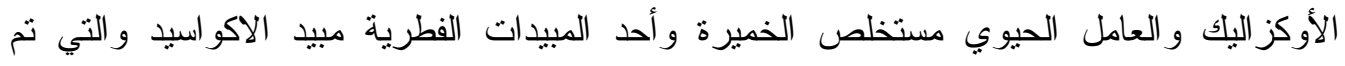

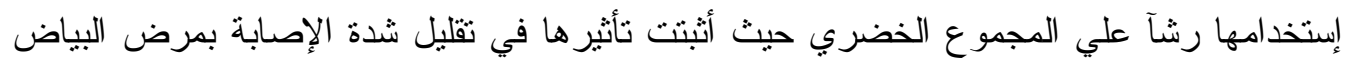
الزغبي في الخيار المنسبب عن فطر Pseudoperonospora cubensis تحت ظروف الصوبة و الحقل.

أثنتت النتائج المتحصل عليها من التجارب المعملية أن المستحثات الكميائية و العامل الحيوي

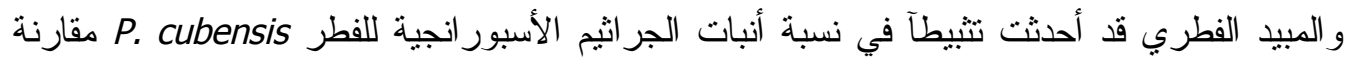
بمعاملة الكنترول.

أوضحت النتائج أيضاً أن كلا من المبيد الفطري و العامل الحيوي كانا أفضل هذه المعاملات

في تثبيط الجر اثيم الأسبور انجية عن المواد المستحثنة الكميائية المختبرة.

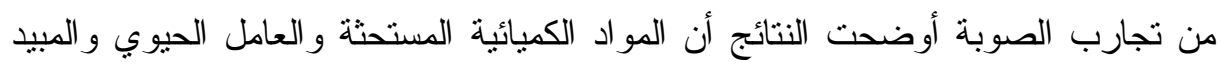
الفطري قد أدت الي نقصآ معنوياً في شدة الإصابة بمرض البياض الزغبي وزيادة معنوية في كلاً من طول النبات و الوزن الطازج للنبات.

كما أوضحت النتائج المتحصل عليها من التجارب الحقلية أن كل من المبيد الفطري و العامل

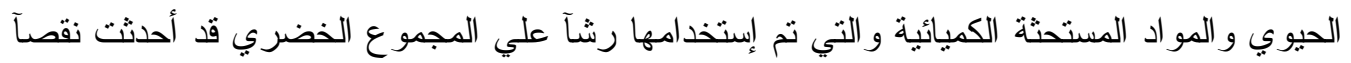
معنويآ في شدة الإصابة بمرض البياض الزغبي حيث كان متوسط النتائج المتحصل عليها هي ,7.25

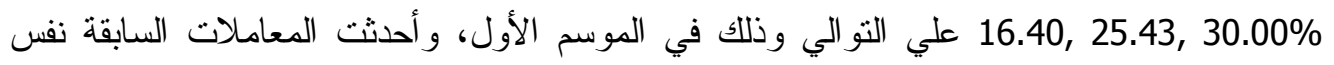
الأتجاه أيضاً في الموسم الثاني حيث كان منتسط النتائج هي

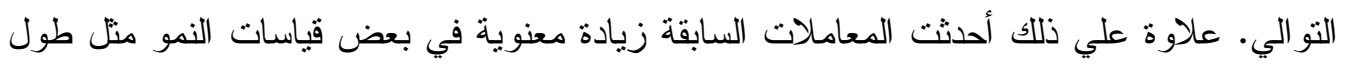

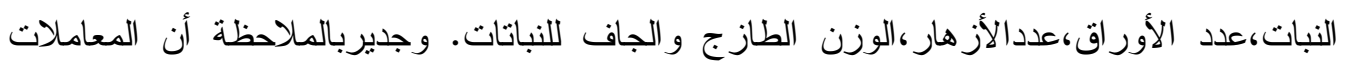

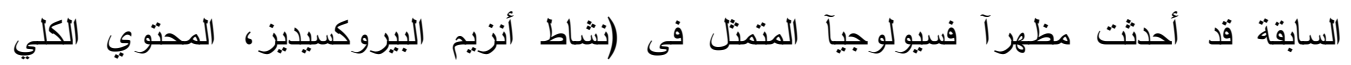

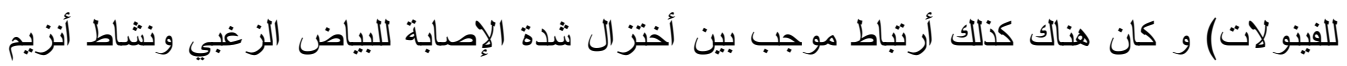
البيروكسيديز و المحتوي الكلي للفينو لات. 
